\title{
Knowledge Mapping of Grassroots Consultative Democracy Research in China (2004-2020) - Bibliometric Analysis Based on CNKI Database
}

\author{
Ying Duan ${ }^{1}$, Ying Zhang ${ }^{1} \&$ Yi-Luo Wang ${ }^{1}$ \\ ${ }^{1}$ Shandong Technology and Business University, Yantai, Shandong, China \\ Correspondence: Ying Duan, Shandong Technology and Business University, Yantai, Shandong, China. E-mail: \\ duanying206@163.com
}

Received: March 19, 2021 Accepted: April 6, 2021 Online Published: April 8, 2021

doi:10.5539/par.v10n1p58 URL: http://dx.doi.org/10.5539/par.v10n1p58

\begin{abstract}
Since 2003, the term "consultative democracy" has received more and more attention from Chinese scholars, and more research results have been formed. In general, these documents lack the analysis of the research stage and research hotspots in this field. Therefore, this article uses the Chinese Academic Journals Network Publishing Library (CNKI) as the data source, and uses the common word analysis and cluster analysis methods in the CiteSpace software to analyze 500 Chinese core journals in the field of grassroots deliberative democracy in my country from 2004 to June 2020. The literature conducts a text quantitative analysis. The study found that the research hotspots of grassroots deliberative democracy in our country focused on Chinese characteristics, party leadership, national governance and political consultation. Compared with capitalist democracy, socialist democracy with Chinese characteristics is a comprehensive, extensive and true democracy, and the realization of democratization at the grassroots level is the unity of electoral democracy and deliberative democracy. Based on the above research results, the following suggestions are proposed: focus on improving the ability of grassroots masses to consult democracy; in the context of the new era, broaden the development path of grassroots consultative democracy.
\end{abstract}

Keywords: deliberative democracy at the grassroots level, CiteSpace, Chinese characteristics, bibliometric analysis

\section{Introduction}

The theory of deliberative democracy originated in western countries in the 1980s. In 2006, the "Opinions of the CPC Central Committee on Strengthening the Work of the CPPCC" pointed out that consultative democracy is a major way to promote the reform of the political consultation system. The report of the 18th National Congress of the CPC clearly proposed to "actively carry out democratic consultation at the grass-roots level", and the report of the 19th National Congress of the Communist Party of China added the term "democratic consultation" on the basis of the four democracies of villager autonomy. Under the promotion of the Party and the government, the research of deliberative democracy by Chinese scholars grows naturally. In this context, the existing research results in this field were analyzed by using CiteSpace, sort of the development of the study of deliberative democracy at the grassroots level in China, focusing on the hot spots and problems, accurately recognize and grasp the future direction of deliberative democracy at the grassroots level research in China, the development of the practice of deliberative democracy at the grassroots level of China has a certain reference value.

\section{Research Methods and Data Sources}

Based on China academic journal network publishing pool (CNKI) as the data source, a 2004-2020 in Chinese core journals in CSSCI, SCI, EI, deliberative democracy at the grassroots level of related papers published on CSCD as the research object, with keywords "deliberative democracy at the grassroots level" as the retrieval conditions, a preliminary to retrieve the 510 data (retrieving date will be on June 5, 2020). To ensure the scientific nature and accuracy of the research, some book reviews, interviews, academic seminar reviews, meeting minutes, letter of soliciting for papers and repeated publications were manually screened out one by one, and 500 literatures were finally screened out.

In this paper, the scientific knowledge mapping method and bibliometric method are used to visualize the main 
contents and evolutionary paths of research on consultative democracy in China using co-word analysis and cluster analysis in CiteSpace software.

\section{Findings}

\subsection{The Evolution}

The CiteSpace emergent word detection technology was used to draw the research topics of deliberative democracy at the grassroots level in China and to display the knowledge map. The knowledge map of the top 12 emergent hotspots in deliberative democracy research at the grassroots level was generated according to the ranking of emergent rates (Table 1). These keywords are representative terms in the field of grassroots deliberative democracy research in China, which basically cover the hotspots and key points of domestic research on grass-roots deliberative democracy, and represent the hot topics of research in the development process of this field. It can be seen that the key words that attract more attention in a specific period of time include deliberative democracy, grass-roots democracy, socialist deliberative democracy, party leadership, Chinese characteristics, which are the forefront issues in the field of grass-roots deliberative democracy research at present.

On the whole, the research on deliberative democracy at the grass-roots level in China can be divided into three stages, which gradually reflect Chinese characteristics. The first stage, from 2006 to 2014, is a preliminary discussion on the form of deliberative democracy at the grassroots level in China. Yu Keping(2003), Lin Shangli (2003), Chen Jiagang (2005) and others first started to study the basic connotation, values and development path of deliberative democracy based on China's national conditions.

In the second stage, after 2014, as shown in the Table 1, "grass-roots social governance", "grass-roots consultation" and other words constitute prominent words in the study of deliberative democracy. The Third Plenary Session of the 18th CPC Central Committee proposed to promote the modernization of national governance system and governance capacity, and one of the demands of developing deliberative democracy of socialism with Chinese characteristics is to promote the modernization of national governance system and governance capacity. Therefore, many scholars in China at the grassroots level, especially the study of rural democratic consultation, some scholars direct negotiations in rural grassroots democracy test, prove that inject consultation factors in rural China, will better protect the basic rights and interests of the villagers, improve the level of rural democracy (He Baogang 2007). Gradually in some places have produced some new form of democracy, such as hearing and council, the villagers of democratic talkfest and Internet public BBS, etc., and summarized as decision-making consultation management mechanism, the hearing sex consultation management mechanism, the consultative consultative governance mechanism and governance mechanism, coordination consultation appraisal consultation governance mechanism.

In the third stage, from 2018 to 2020, the prominent words of deliberative democracy research are "Party leadership", "new era" and "Chinese characteristics". Specifically, the existing research on consultative democracy from the perspective of Chinese characteristics focuses on the following three aspects: The first is the historical origin and local orientation. In traditional Chinese society, "Official Admonition and Counseling" originated in the era of Yao and Shun. The public discussion on politics proposed by the thinker Wei Yuan in the late Qing Dynasty on the basis of the system of remonstrance officials. In the qin dynasty was established toward the discussion system contain rich negotiation factors. In modern Chinese society, the "three-three" regime formed during the War of Resistance Against Japan and the People's Commune Movement after the founding of New China had a typical spirit of negotiation and connotation. Second, China's concrete practice. The "Democratic Talkfest" held in Wenling City, Zhejiang Province, was affirmed by some scholars as a typical case of consultative politics in grassroots practice. Since the 18th National Congress of the Communist Party of China (CPC), deliberative democracy with Chinese characteristics has been explored and innovated at all levels in China. The beneficial practice of deliberative democracy at the grassroots level has added new value to socialist deliberative democracy, and Western theories of deliberative democracy have been gradually localized. The practice of rural democratic consultation with Chinese characteristics is based on the leadership of rural grassroots party organizations and the rural grassroots democratic system, various political forces in rural areas boldly explore different forms of consultation with Chinese characteristics, with multiple subjects governing together and participants in consultation having dialogue with each other to form consensus on rural development and realize the interests of farmers. Third, the new connotation under the new era background. Under the background of the new era, actively and steadily developing deliberative democracy at the grassroots level is an inevitable requirement for the development of socialist democratic politics, an urgent need to promote the modernization of social governance at the grassroots level, and an important way to realize the interests of different stakeholders. Therefore, under the background of the new era, we should further release the institutional advantages of deliberative democracy of 
socialism with Chinese characteristics and highlight its unique value.

Tabie 1. Top 12 keywords with the strongest citation bursts

\begin{tabular}{lll}
\hline \multicolumn{1}{c}{ Keywords } & Strength & Phases \\
\hline Counsel democracy & 3.5537 & $2006-2012$ \\
Grassroots democracy & 2.3647 & $2007-2011$ \\
Democracy communion & 2.1487 & $2009-2014$ \\
Socialist consultative democracy & 2.0354 & $2013-2015$ \\
Rural & 1.8923 & $2015-2016$ \\
National governance & 2.3894 & $2015-2018$ \\
Social governance at the grassroots level & 2.4334 & $2016-2017$ \\
Grass-roots consultations & 2.1698 & $2016-2017$ \\
Consultative democracy at the grassroots & 4.018 & $2017-2018$ \\
Leadship of the Party & 2.6997 & $2018-2020$ \\
New age & 1.7955 & $2018-2020$ \\
Chinese characteristics & 1.8304 & $2019-2020$ \\
\hline
\end{tabular}

\subsection{Cluster Analysis of the Research on Deliberative Democracy at the Grass-Roots Level in China}

In this paper, LLR (Log-Likelihood Ratio) is used for clustering analysis. Combining the clustering results with the above high-frequency keywords and research evolution rules, the research hotspots of China's grass-roots deliberative democracy focus on grass-roots deliberative democracy, political consultation, electoral democracy, villagers' autonomy, and grass-roots governance. (Figure 1)

Grassroots consultative democracy. The report to the 18th National Congress of the Communist Party of China put forward the concept of "socialist deliberative democracy" for the first time, and clearly pointed out that socialist deliberative democracy is an important form of people's democracy in China. Through the analysis of the literature samples, it is found that rural areas are relatively concentrated in the research on grassroots deliberative democracy, indicating that rural areas are the main targets of grassroots deliberative democracy research in China. The current rural grassroots village debts, land ownership and other issues are prominent. Encourage the grassroots to participate in political life and participate in extensive democratic consultations. Ning Youcai and Wang Caiyun pointed out that "the development of consultative democracy at the grassroots level cannot be separated from the motivation of governance, interests and theories. The motivation of governance comes from the contradictions of the grass-roots society and forms a governance pressure. Through democratic consultation, all interest subjects can participate in grass-roots governance (Ning Youcai 2013). Extensive democratic consultation and communication has effectively supplemented the deficiencies of democratic effectiveness and procedural legitimacy of electoral democracy "and innovated the governance pattern of grass-roots society.

Political consultation. Although the theory and practice of deliberative democracy originated from the West, there are also different forms of socialist deliberative politics in China. Among them, the one with relatively mature and complete institutional framework is the political consultative system based on the platform of the Chinese People's Political Consultative Conference. The practical basis for the all-round development of consultative democracy in China is political consultation. The multi-party cooperation and political consultation system under the leadership of the Communist Party of China is actually an organic unity of leadership, cooperation and consultation, emphasizing both party leadership and socialist democracy. The political consultation system, based on multiparty cooperation and the CPPCC, is conducted in response to major national issues and an important manifestation of democratic consultation in national governance. Moreover, the political spirit and principles of leadership, cooperation, unity and democracy embodied in political consultation can run through from the central to the local level, providing a basis for political legitimacy for the development of consultative democracy at the grassroots level.

Electoral democracy. In addition to deliberative democracy, electoral democracy is also an important part of China's democratic political construction. Since the new period, scholars hold different views on electoral democracy and deliberative democracy. Some scholars believe that we should follow the trend of The Times and 
implement "electoral democracy". Combined with China's national conditions, some scholars believe that electoral democracy tends to competition and is not suitable for choosing competitive electoral democracy. There are also some scholars who believe that the coordinated development of electoral democracy and deliberative democracy should be realized and that elections are only the beginning of democratic politics. The process of political operation after elections is more likely to be reflected by other forms of democracy, such as consultative democracy and supervisory democracy. It can be said that electoral democracy is the necessary beginning of democratic politics, and deliberative democracy is the concrete embodiment of democratic politics ${ }^{[6]}$. The interaction of these two forms of democracy can promote political modernization and political stability. Therefore, the construction of grass-roots democracy should be the unity of election democracy and consultative democracy.

Villager autonomy. With the transformation of rural society, villager autonomy needs to be further expanded and deepened. At the 23rd Session of the Standing Committee of the Fifth National People's Congress held in 1982, "villagers' autonomy" was included in the draft amendment to the Constitution, which was finally formally affirmed and legally confirmed in the Constitution of the People's Republic of China adopted at the Second Session of the Fifth National People's Congress. Thus, the villagers' committee has been rapidly established in the vast rural areas of China. As a new thing of rural governance, the rules and procedures of villager autonomy system have undergone a change from simple and rough to detailed and concrete. However, with the change of the social situation in rural areas and the diversification of farmers' demands, the villagers' self-government system is facing new challenges. The deliberative democracy plays a unique role in the aspects of subject tolerance, information sharing, social solidarity, multiple identity and social rule of law. It has become the only way to regain the value of the villagers' self-government system.

Grassroots governance. At the Third Plenary Session of the 18th CPC Central Committee, it was proposed to realize the modernization of national governance capacity and governance system. The urban and rural grass-roots units directly face the general public, are closest to the people's production and life, and are also the end of the state power, playing a fundamental role in the country's political and social and economic life. Community-level governance in urban and rural areas connects cities on one end and rural areas on the other. It is vital to urban and rural development and social stability. The accelerating the process of urban and rural grassroots democracy development in China, in the face of the new normal diversity at the grass-roots level of synergy, weak participation, the conflict at the grass-roots level and the village community or villagers' autonomy, in democratic elections as the main form of democracy at the grassroots level gradually cannot meet the needs of urban and rural residents to participate in social governance, consultative governance can maximum range provoked a public participation, openness and response to social governance characteristics can do response to the greatest extent.

From the analysis of the above clusters, it can be found that villagers' self-governance is the starting point, electoral democracy is the key point, and grassroots consultative democracy, political consultation and grassroots governance are the important supplementary contents of grassroots democracy. At present, grass-roots democracy is developed in the coordination of electoral democracy, deliberative democracy and political consultation. We should promote the development of grass-roots democracy by promoting the role of democratic consultation within the Party and outside the Party. 

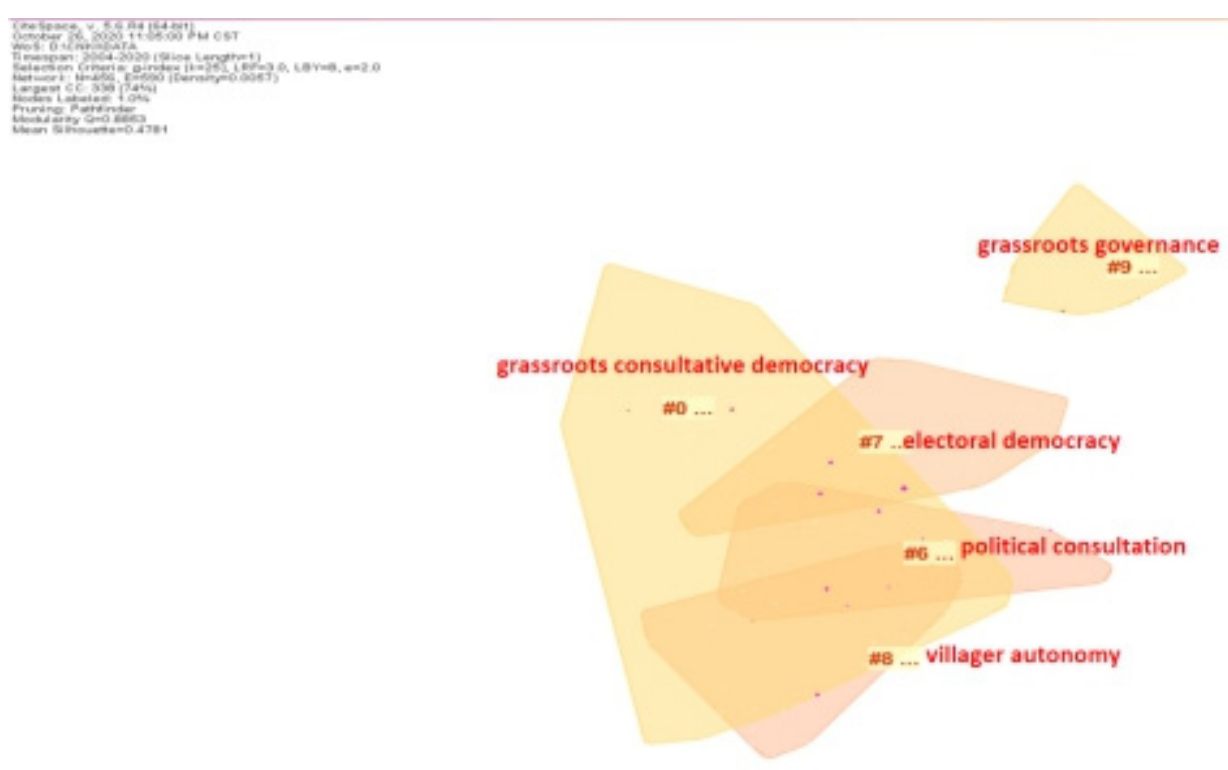

Figure 1. Clustering map of grass-roots deliberative democracy research in China from 2014 to 2020

\section{Conclusions}

\subsection{Research Conclusion}

Based on the scientific measurement of the research results in the field of deliberative democracy at the grass-roots level in China from 2004 to 2020, this paper shows some regularities and characteristics of the research on deliberative democracy at the grass-roots level in China.

In China, the research on deliberative democracy at the grass-roots level started late, but it develops rapidly due to the national attention and the promulgation of policies. From the perspective of emergent words and hot content of grass-roots deliberative democracy research, grass-roots deliberative democracy research has experienced the process of introducing western theoretical concepts at the beginning to focusing on local experience. After experiencing rapid growth, the research topics tend to be diversified and refined. In grassroots governance, deliberative democracy emphasizes the equal status of all participants, consultation on an equal footing, and joint realization of governance goals, which is in line with the modernization trend of China's national governance system and governance capacity. However, under the situation that the pattern of rural interests has changed and the interest demands of villagers are increasingly diverse and complex, the consultative democracy at the grassroots level should be actively developed on the basis of villagers' autonomy.

\subsection{Research Prospects}

With the continuous maturity of the theory of deliberative democracy indigenization, forms of grassroots consultations such as democratic talks and village group consultations continue to emerge. However, due to the short time of discussion on grassroots deliberative democracy and the few scholars who are specialized in the research, the system supply of grassroots deliberative democracy in China is lacking. Under this background, the grassroots society needs to continuously explore and establish the corresponding deliberative system to steadily promote the rural revitalization strategy.

From the knowledge map of deliberative democracy at the grassroots level in China, we can find that there is no "public participation" in either the keyword emergence map or the cluster analysis map. As a recent development of democratic theory and practice, deliberative democracy emphasizes the importance of citizen participation. Especially in the context of consultative democracy, people are more willing to participate in consultation and express their demands. However, in the rural environment, the villagers' negotiation ability is significantly insufficient. If the consultation procedure and rules are not followed, the consultation process will cause the destruction of public rationality. It can be seen that negotiation ability is the core element of negotiation, which affects the quality and development of negotiation. Therefore, scholars in the field of deliberative democracy research can focus on how to effectively improve the ability of individuals in grass-roots organizations to participate in deliberative democracy, and give constructive countermeasures and suggestions. 
Consultative democracy represents a new direction for the development of grassroots democracy in China. Under the background of the new era, scholars should constantly improve the connotation and extension of deliberative democracy of socialism with Chinese characteristics. We will focus our attention on the practice and institutional issues of consultative democracy, draw on practices at the community level, draw on advanced experience from local reforms, and actively explore these issues under the leadership of the Party. We will continue to enrich the forms of consultative democracy at the community level, improve the system of consultative democracy at the community level, and further promote the development of consultative democracy and governance at the community level.

\section{References}

Chen, J. G. (2005). Deliberative Democracy: Concepts, Elements and Values. Journal of Party School of CPC Tianjin Committee, (03), 54-60.

He, B. G, (2007). Wang Chunguang. Rural consultative democracy in China: A case study. Sociological Research, (03), 56-73+243.

Lin, S. L. (2003). Consultation Politics: A Reflection on the Development of Chinese Democratic Politics. Academic Journal, (04), 19-25.

Ma, B. C. (2013). How to Understand the Relationship between Electoral Democracy and Consultative Democracy. China Party and Government Cadres Forum, (7).

Ning, Y. C., \& Wang, C. Y. (2013). Analysis on the motivation of promoting consultative democracy at the grassroots level. Shandong Social Sciences, (10), 116-121.

Yu, K. P. (2003). Hot Issues in Contemporary Western Political Theory. Theoretical Reference, (01), 29-31.

\section{Copyrights}

Copyright for this article is retained by the author(s), with first publication rights granted to the journal.

This is an open-access article distributed under the terms and conditions of the Creative Commons Attribution license (http://creativecommons.org/licenses/by/4.0/). 